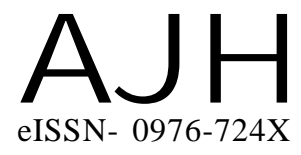

Received : 22.10.2017

Revised : 20.11.2017

Accepted : 28.11 .2017

Members of the Research Forum

Associated Authors:

${ }^{1}$ Department of Horticulture,

Agricultural College and

Research Institute (T.N.A.U.),

MADURAI (T. N.) INDIA
Author for correspondence : V. KRISHNAMOORTHY

Department of Horticulture, Agricultural College and Research Institute (T.N.A.U.), MADURAI (T. N.) INDIA

Email : krishorttnau@gmail.com
THEASIAN JOURNAL OF HORTICULTURE

Volume 12 | Issue 2 | December, 2017 | 260-266

Visit us -www.researchjournal.co.in

RESEARCH PAPER

DOI : 10.15740/HAS/TAJH/12.2/260-266

\section{Per se performance of pumkin (Cucurbita moschata Duch ex Poir) hybrids for yield and quality}

\section{P. MARXMATHI ${ }^{1}$ AND V. KRISHNAMOORTHY}

ABSTRACT : An investigation was conducted at Department of Horticulture, Agricultural College and Research Institute, Madurai during 2016-2017 to study the per se performance of pumpkin hybrids evolved with diallel analysis with thirty hybrids were obtained through diallel mating design with six parents viz., $\mathrm{P}_{1}$ : Acc.No.MDU CM23 - Thirumangalam local, Madurai district, $\mathrm{P}_{2}$ : Acc.No.MDU CM28 - Oddanchatram local, Dindugul district, $\mathrm{P}_{3}$ : (Acc.No.MDU CM29- Harur local, Dharmapuri distict, $\mathrm{P}_{4}$ : Acc.No.MDU CM12, Department of Horticulture, AC and RI, Madurai, $\mathrm{P}_{5}$ : Acc. No.MDU CM1 - Attur local, Salem district, $\mathrm{P}_{6}$ : Acc.No.MDU CM31 - Rajapalayam local, Virudhunagar district for yield and quality traits in pumpkin (Cucurbita moschata Duch. ex. Poir). The per se performance of parents and hybrids showed that the parents $\mathrm{P}_{1}(8.46), \mathrm{P}_{4}(9.36)$ and $\mathrm{P}_{6}$ (4.55) were high yielding and bigger sized fruits. Among the thirty crosses, six cross combinations viz., $\mathrm{P}_{1} \times \mathrm{P}_{3}(12.38), \mathrm{P}_{1} \times \mathrm{P}_{2}$ (11.79) $\mathrm{P}_{1} \times \mathrm{P}_{5}(8.18)$, $\mathrm{P}_{1} \times \mathrm{P}_{5}$ (11.66), $\mathrm{P}_{1} \times \mathrm{P}_{6}(8.55)$ and $\mathrm{P}_{4} \times \mathrm{P}_{1}$ (12.08) recorded higher values for yield per vine, fruit weight (6.13 to $10.15 \mathrm{~kg}$ ), vine length (6.54 to 8.22), higher sex ratio (17.05 to 24.06). The smaller sized fruits were obtained in five cross combinations viz., $\mathrm{P}_{2} \times \mathrm{P} 1(1.54), \mathrm{P}_{2} \times \mathrm{P}_{3}(1.78), \mathrm{P}_{2} \times \mathrm{P}_{4}(1.79)$, $\mathrm{P}_{2} \times \mathrm{P}_{5}$ (2.02) and $\mathrm{P}_{2} \times \mathrm{P}_{6}(1.68)$ with the fruit size ranged from 1.54 to $1.79 \mathrm{~kg}$.

KEY WORDS : Per se, Pumkin, Cucurbita moschata, Hybrids, Carotene

HOW TO CITE THIS ARTICLE : Marxmathi, P. and Krishnamoorthy, V. (2017). Per se performance of pumkin (Cucurbita moschata Duch ex Poir) hybrids for yield and quality. Asian J. Hort., 12(2) : 260266, DOI : 10.15740/HAS/TAJH/12.2/260-266. 